\title{
ARTIGO
}

do https://doi.org/10.22481/praxisedu.v16i37.6404

\section{EDUCATIONAL POTENTIAL OF INFORMATION AND COMMUNICATION TECHNOLOGIES IN PATRIOTIC EDUCATION OF STUDENTS}

\author{
POTENCIAL EDUCATIVO DE LAS TECNOLOGÍAS DE LA INFORMACIÓN Y LA \\ COMUNICACIÓN EN LA EDUCACIÓN PATRIÓTICA DE LOS ESTUDIANTES
}

\author{
POTENCIAL EDUCACIONAL DAS TECNOLOGIAS DE INFORMAÇÃO E \\ COMUNICAÇÃO NA EDUCAÇÃO PATRIÓTICA DE ESTUDANTES
}

Vyacheslav Shynkarenko

Dnipro Academy of Continuing Education of Dnipropetrovsk Regional Council - Ucrânia

\begin{abstract}
Olha Perederii
Dnipro Academy of Continuing Education of Dnipropetrovsk Regional Council - Ucrânia
\end{abstract}

Ivan Bezena

Dnipro Academy of Continuing Education of Dnipropetrovsk Regional Council - Ucrânia

Yevheniia Velykodna

Dnipro Academy of Continuing Education of Dnipropetrovsk Regional Council - Ucrânia

Andrii Miroshnychenko

Dnipro Academy of Continuing Education of Dnipropetrovsk Regional Council - Ucrânia

\begin{abstract}
The educational potential of information and communication technologies in the patriotic education of students is investigated and substantiated in the article. Conducting a pedagogical experiment, it has been theoretically substantiated and practically proved the efficiency of using information and communication technologies in students' patriotic education. The experience of work of secondary educational institutions on patriotic education is analyzed, diagnostic methods for studying the level of students' patriotic education in institutions of general secondary education are selected and implemented. The set of applied diagnostic methods aimed at revealing the educational potential of information and communication technologies in students' patriotic education is substantiated. We also have worked out the system of quality indicators of the main components of patriotic educatedness and criteria. Based on analysing psychological and pedagogical literature and studying scientists' ideas, four levels of patriotic education have been scientifically substantiated by certain criteria and indicators. Scaling of the corresponding criteria of indicators taking into account indicators of their appearance in $0-3$ points is carried out.
\end{abstract}

Keywords: Information and communication technologies; Patriotic education; Education institutions; Innovative development. 
Resumen: El potencial educativo de las tecnologías de la información y la comunicación en la educación patriótica de los estudiantes se investiga y confirma en el artículo. Llevando a cabo un experimento pedagógico, se ha comprobado teóricamente y prácticamente ha demostrado la eficacia del uso de tecnologías de información y comunicación en la educación patriótica de los estudiantes. Se analiza la experiencia de trabajo de las instituciones de educación secundaria en educación patriótica, se seleccionan e implementan métodos de diagnóstico para estudiar el nivel de educación patriótica de los estudiantes en instituciones de educación secundaria general. Se confirma el conjunto de métodos de diagnóstico aplicados destinados a revelar el potencial educativo de las tecnologías de la información y la comunicación en la educación patriótica de los estudiantes. También hemos elaborado el sistema de indicadores de calidad de los principales componentes de la educación y los criterios patrióticos. Basado en el análisis de la literatura psicológica y pedagógica y el estudio de las ideas de los científicos, cuatro niveles de educación patriótica han sido científicamente fundamentados por ciertos criterios e indicadores. Se lleva a cabo la escala de los criterios correspondientes de los indicadores teniendo en cuenta los indicadores de su aparición en 0-3 puntos.

Palabras clave: Tecnologías de la información y la comunicación; Educación patriótica; Instituciones educativas; Desarrollo innovador.

Resumo: O potencial educacional das tecnologias da informação e comunicação na educação patriótica dos alunos é investigado e fundamentado no artigo. Conduzindo um experimento pedagógico, foi comprovado teoricamente e praticamente comprovou a eficiência do uso de tecnologias da informação e comunicação na educação patriótica dos alunos. A experiência do trabalho de instituições de ensino médio em educação patriótica é analisada, métodos de diagnóstico para estudar o nível de educação patriótica dos alunos em instituições de ensino médio geral são selecionados e implementados. O conjunto de métodos de diagnóstico aplicados com o objetivo de revelar o potencial educacional das tecnologias da informação e comunicação na educação patriótica dos estudantes é fundamentado. Também elaboramos o sistema de indicadores de qualidade dos principais componentes da educação e dos critérios patrióticos. Com base na análise da literatura psicológica e pedagógica e no estudo das idéias dos cientistas, quatro níveis de educação patriótica foram cientificamente substanciados por certos critérios e indicadores. A escala dos critérios correspondentes de indicadores que levam em conta indicadores de sua aparência em 0-3 pontos executa-se.

Palavras-chave: Tecnologias da informação e comunicação; Educação patriótica; Instituições de ensino; Desenvolvimento inovador.

\section{Introduction}

The socio-economic situation in Ukraine today is largely determined by globalization, which in one way or another destructively affects the traditional national culture and the corresponding value system. Such scientists Chernog (2012), Zyazyun (2000), state that the current cultural crisis in Ukraine largely depends on a change in people's psychology. The system of former spiritual values and ideas has been lost and the new one has not been developed yet. In turn, the system of false values of "mass" culture and subcultures is spreading: 
aggression, vandalism, hedonism, freedom without responsibility, power cult. Hence one of the pressing and urgent issues touches patriotic education of the younger generation.

Patriotic education within the educational process in general secondary educational institutions has always been one of the most important tasks for the school, as school age is the most appropriate time to cultivate love for the Motherland. In our opinion, students should gradually develop a sense of pride for their homeland and their Ukrainian people, respect and pride for its great achievements and historic victories. A lot of aspects depend on the modern secondary educational institution: its role in this difficult task cannot be overstated (Bukanov, Kolesnyk, Tashkinova, Kotlubai, Koval, 2019). The problem is that nowadays school patriotic education has almost come down, as they say, "to zero". Many factors have contributed to this over the last few years: the increased media coverage on the wrong path of Ukraine's development, the lack of a common or basic state ideology. In addition, patriotic education is complicated by the lack of methodological literature, in which teachers could find and use recommendations and advice on the problem, developed teaching methods and information and communication technologies in this area. We are convinced that if a teacher in a general secondary educational institution while his/her daily work systematically refers to the materials of the manuals on patriotic education, uses the potential of information and communication technologies, it will allow him/her to grow a new generation of noble and dedicated people who are ready to perform an exploit for Ukraine's sake, who we call patriots.

\section{Literature Review}

In Ukraine, the problems of students' patriotic education were investigated by Voloshin (1985), Vygotsky (1991), Dukhnovich (2009), Kapska (2001), Franko (2016) and others. The problem of patriotic education of the younger generation was discussed by prominent foreign and national scientists, for example, the academician of the Academy of Pedagogical Sciences of Ukraine O. Zakharenko described and tested his school-family model based on personal sense of his/her small homeland, careful attitude towards it.

The Honored Education Worker of Ukraine, Kononeco (2003) being the head of Kirovograd Secondary School № 21 conducted his pedagogical experiment on developing patriotism frame (grounded on heroic traditions of Ukrainian Cossacks).

The views of the academician of the Academy of Pedagogical Sciences of Ukraine Beha (2015)on the speaking task as "a subject to a subject" interaction between the teacher and 
the student are particularly important. The result of this interaction is the student's ability to consciously and voluntarily maintain the teacher's instructions and ideas, which promotes the personal development, including establishement of patriotism.

The problems of patriotic education were studied by foreign scientists. For example, Marshall (1945) worked out the theoretical and methodical priciples of military revolt in the USA based on partiotism; Cichosz (2013) substantiated the model of patriotic education based on integration of educational process; Frączek (2006) found the criteria and indicators of students' patriotic educatedness and substantiated pedagogical conditions of patriotic education based on Regional Studies Through History; Janiga (2004) proved the effeciency of structural and functional model of patriotic education in German schools; Muszyński (1996) described categorization boundaries between "patriotism" and "nationalism" and determined the levels of students' patriotic educatedness within educational process. Chace (1997) prepared the list of the main subjects which gave a wide range of opportunities for students'patriotic education; George (1993) thought that civic organisations played an important role in educating a citizen of any country which should encourage developing the patriotic fundamentals, national and cultural identities.

Also, the analysis of scientific sources shows that the problem and experience of forming students' citizenship in the EU countries have not been studied and applied in Ukraine, which would contribute to students' civic education and their transition to a higher quality level (Bodnar, Mirkovich, Koval, 2019) as well as changing the system of social security (Borychenko, Hudz, Koval, Golubkova, Mazur, 2019) and labor market (Koval, Polyezhayev, Bezkhlibna, 2018).

In Poland the dominant role in civic education is given to the formation of patriotism. The "Patriotism of Tomorrow" program has been developed and is currently being implemented. According to it, national flag days are celebrated; propaganda broadcast on radio and videos on television are based on patriotic songs about the Republic of Poland, guided by the principles of the rule of law, solidarity and justice. The program is mainly aimed at young people who are encouraged to stay in their homeland and build their future there. Patriotic education in Poland starts from preschool age. Children from the kindergarten are taught about their national coat of arms and flag, they learn the national anthem of Poland, and they are brought up local patriotism. Preschoolers are taken to their hometown museums, monuments, and told about local heroes and local traditions. 
Modern philosophy interprets "patriotism" as a phenomenon, a moral and political principle, the content of which contains love for the Motherland, pride in its present and past, commitment to the interests of the native country and the desire for its protection (Shynkaruk, 1986).

In the psychological and pedagogical literature the concept of "patriotism" is also interpreted differently. For example, in "Pedagogical Dictionary" patriotism is defined as "love for the Motherland, for its people" and Soviet patriotism was understood as "the feeling of love of the Soviet people for the socialist Motherland. It is inextricably linked to any manifestation of bourgeois nationalism, chauvinism and cosmopolitanism"(Goncharenko, 1997).

The authors of almost all scientific works believe that patriotism is an activity for the benefit of the Motherland and love for it. We have noticed the coincidence of the views of scholars with the most authoritative periodical Larousse, where Patriotism is the love to the country, the Motherland, the place of birth, the desire to protect own land and own values (Mishchenko, 2004).

The purpose of the article is to theoretically substantiate and practically prove the use of ICT as a means of students' patriotic education in the educational process of general secondary educational institutions. The objectives of the study are: to develop criteria and indicators for assessing the levels of students' patriotic educatedness in the educational process of general secondary educational institutions; to describe levels of students' patriotic educatedness while ascertaining and formative stages of the pedagogical experiment; to generalize information on changing dynamics in students' patriotic education levels; to form conclusions on effectiveness of applying information and communication technologies within educational process in institutions of general secondary education as a means of patriotic education.

\section{Results}

At the ascertaining stage of the experiment, we aimed to determine the state of patriotic education in the educational process of general secondary educational institutions. The stage included analysis of work on patriotic education of general secondary educational institutions, selection of methodology, techniques and methods of diagnosing the level of students' patriotic education; the results were analyzed.

The experiment was conducted under natural conditions of the educational process of general secondary educational institutions (№ 5, №10, №14, №47 in Dnipro, №28, №75, №26 
in Kryvyi Rih), and some provisions of the dissertation were checked among teachers, who worked with school leavers, students, teachers who improved their qualification at advanced training courses of "Dnipro Academy of Continuing Education", Kryvyi Rih Pedagogical Institute of the State Pedagogical University "Kryvyi Rih National University", Uman State Pedagogical University named after Pavlo Tychyna, Kirovohrad State Pedagogical University named after Volodymyr Vynnychenko.

Experimental and control groups of students in forms 10-11 of general secondary education were selected as the basis for the ascertaining experiment. In total, 45 teachers, 567 students, 281 of them in the experimental group and 286 of them in the control group participated in the experimental work.

The criteria for choosing the students were: approximately the same level of ideas about patriotism, their number in classes.

At the ascertaining stage of the experiment, based on different approaches of teachers and psychologists to determine the formation of students' patriotic educatedness, we developed a system of quality indicators of the main components of patriotism. All these indicators are closely interrelated and interdependent. They can characterize several components of the students' patriotic educatedness: cognitive, emotional and motivational, activity-creative, ethno-identification (Shynkarenko, 2018).

The selection of patriotic-oriented tasks was envisaged: using the Ukrainian language, forming a deeper language culture, developing spiritual values, developing interest in the tasks of patriotic orientation, caring for people with special needs, promoting respect for parents and the elderly, encouraging state and military service in the army.

We used pedagogical methods and techniques to test the hypothesis of the research and to solve the set tasks. The main methods in the study were: system, modeling, comparison, historical and bibliographic, generalization of experience (Kvitka, Starushenko, Koval, Deforzh, Prokopenko, 2019). Empirical methods included: experimental methods ascertaining and forming experiments, questioning, testing, observation, expert evaluation. At each of the stages different methods of cognition were used, which made up a complex methodology of the research.

The study was conducted in three stages (preparatory, basic, final).

The main steps of the ascertaining experiment were: attending and analyzing lessons with applying ICT in high school; observing students' creative activity at the lessons and analyzing their results; holding individual conversations with students and teachers; questioning students 
with the help of ICT; analysing the results of experimental tasks with using ICT, students' creative work; observing extracurricular work in high school.

The study of the level of students' patriotic educatedness was conducted on the basis of the developed criteria, namely: value-patriotic outlook; patriotic-directed activity; patriotic creative activity; personification and cultural identification of the individual.

Based on the analysis of the psychological and pedagogical researches by Demianchuk (2019), Machuska (2003), Pustovit (2015), the study of the scientists' opinions, the analysis of the state of students patriotic educatedness we developed and scientifically substantiated four levels of patriotic educatedness by certain criteria and indicators (high, sufficient, medium, low).

The set of diagnostic methods, we used at the control/final assessements (questionnaires, testing, interviews, performing creative tasks, various questionnaires), should reveal the level of development of a certain indicator of students' patriotic educatedness. For this purpose, the scaling of the corresponding criteria indicators taking into account their appearance in points (0-3 points) was carried out. According to the total number of points for each of the indicators, the level of formation of the investigated quality was determined according to this or that criterion. Diagnosis of the general level of students' patriotic educatedness was carried out by the developed methodology.

Then we presented the results obtained and their analysis. Interviews of students (567 people) and teachers in senior school (62 people) were conducted according to the set program (questionnaire). The interviewees included school staff who had a pedagogical background and the ability to easily communicate with the interlocutor, could easiely ask questions, manage the interview. Employees interviewing high school teachers and students followed the rules we had developed. The interview lasted no more than 20 minutes in the form of a casual conversation with no strangers. We recorded the students' answers in the notebook, then processed and decrypted them for recording in a standard questionnaire.

The questionnaires were compiled with the modern requirements. While preparing the questionnaires particular attention addressed to forming questions which were subjected to primary standardization to be sure that the students would understand them correctly and unambiguously, and also they were tested on simplicity and accessibility of their subsequent processing.

The next stage of the ascertaining experiment was to identify the existing levels of students' patriotic educatedness. For this purpose, we used specially designed tasks related to 
the content of the curriculum and designed for students' percepting folk values, comparing them, expressing creative imagination, forming judgments about a particular patriotic phenomenon.

To use and caclulate the data results of the study easily and comfortably, we introduced a reduction of the names of the criteria of students' patriotic educatedness: $C a$ - the criterion of "Patriotic-directed activity"; $C c a$ - criterion "Patriotic creative activity"; $C o$ - the criterion "Value-patriotic outlook"; $C p$ - criterion "Personification and cultural identity of the individual".

The results of the experimental work were measured with using statistical methods: methods of quantitative processing of the research results and systematization of quantitative indicators of the experiment.

Accordingly, the outcome of the tasks was evaluated on a scale: 3 points - the indicator is realized; 2 points - the indicator is unclear; 1 point - the indicator is weak; 0 points - there is no indicator.

According to the results of calculating assessment points, the coefficient of formation of a particular indicator of students' patriotism in a particular group was determined as the average numerical value by the formula:

$$
\text { C1.1. }=\frac{\mathrm{n} 1(0)+\mathrm{n} 2(1)+\mathrm{n} 3(2)+\mathrm{n} 4(3)}{\mathrm{n}}
$$

Where, $\mathrm{n}$ - total number of students; $\mathrm{n}_{1}-$ the number of students who received the grade $(0) ; \mathrm{n}_{2}$ - the number of students who received the grade (1); $\mathrm{n}_{3}$ - the number of students who received the grade (2); $\mathrm{n}_{4}$ - the number of students who received the grade (3).

The level of students' patriotic educatedness by one or another criterion was determined as the arithmetic mean of the coefficients of each indicator:

$$
\mathrm{Cb}=\frac{\mathrm{C} 1.1 .+\mathrm{C} 1.2 .+\mathrm{C} 1.3 .+\mathrm{C} 1.4 .+\mathrm{C} 1.5 .}{5}
$$

In turn, the level of students' patriotic educatedness was calculated as the arithmetic mean of the coefficients of each criterion.

$$
\text { Coef. } \mathrm{k} .=\frac{\mathrm{Cb}+\mathrm{Co}+\mathrm{Cs}+\mathrm{Cm}+\mathrm{Cp}+\mathrm{Ce}}{6}
$$

Where, Coef.k. - coefficient of patriotic educatedness; $\mathrm{Ca}$ - the criterion of "Patrioticdirected activity"; $C c a$ - criterion "Patriotic creative activity"; $C o$ - the criterion "Valuepatriotic outlook"; $C p$ - criterion "Personification and cultural identity of the individual".

While determining the levels of students' patriotic educatedness, assessment zones were introduced: 
$0 \leq \mathrm{Kn}<0,66-$ low level of patriotic educatedness;

$0,67 \leq \mathrm{Kn}<1,32$ - average level of patriotic educatedness;

$1,33 \leq \mathrm{Kn}<2,0-$ optimal level of patriotic educatedness;

$2,1 \leq \mathrm{Kn}<3,0-$ high level of patriotic educatedness.

Consider the results obtained.

The survey revealed the students' attitude towards their homeland and understanding of the basic concepts of patriotic content. Among the 10th and 11th form students, 13.5\% answering "Who is a patriot?" stated that "this is a person who lives in Ukraine", $15.7 \%$ of students considered that "this is a person who loves the Motherland", 23.3\% thought that "this is a person who defends his country"; $13.3 \%$ mentined that "this is a person who is not indifferent to the future of the country"; $12.6 \%$ stated that "this is a person who works for the benefit of Ukraine", $17.4 \%$ of them were sure that "this is a person who is experiencing all the problems with Ukraine". Also we should emphasize that $4.2 \%$ of respondents were undecided. The results of the study showed that there were some students who equated the concepts "Motherland" and "the state", which brought a certain contradiction in their views.

When answering the questions "What content do you put into the concept "patriotism"?" and "What does such phenomenon as "patriotism" reveal, in your opinion?" it was shown that the students did not have a common understanding of the concept "patriotism". In particular, more than $85.1 \%$ of them did not reveal the general characteristics of this concept.

We were also interested in how students understood the concept "Motherland". It turned out that $15.1 \%$ of the students were convinced that "the Motherland is the place where you live and fulfill your responsibilities"; $10.3 \%$ of them understood it as "home"; 15,4\% - as "native land"; $15.3 \%$ - as "the land of my people"; $13.4 \%$ of the students thought "it is the place of birth"; $10.3 \%$ considered "it is a place where parents and relatives live", $3.2 \%$ considered "it is a place where you study".

The generalized results of the study of the current levels of students' patriotic educatedness are given in Table 1.

Qualitative analysis of the data in tables 1 and 2 testifies that medium and low levels of students' patriotic educatedness according to all our criteria are dominant.

Table 1. Summary table of the results of the ascertaining study of the students' patriotic educatedness, in \%

Levels of performing indicators of patriotic educatedness 


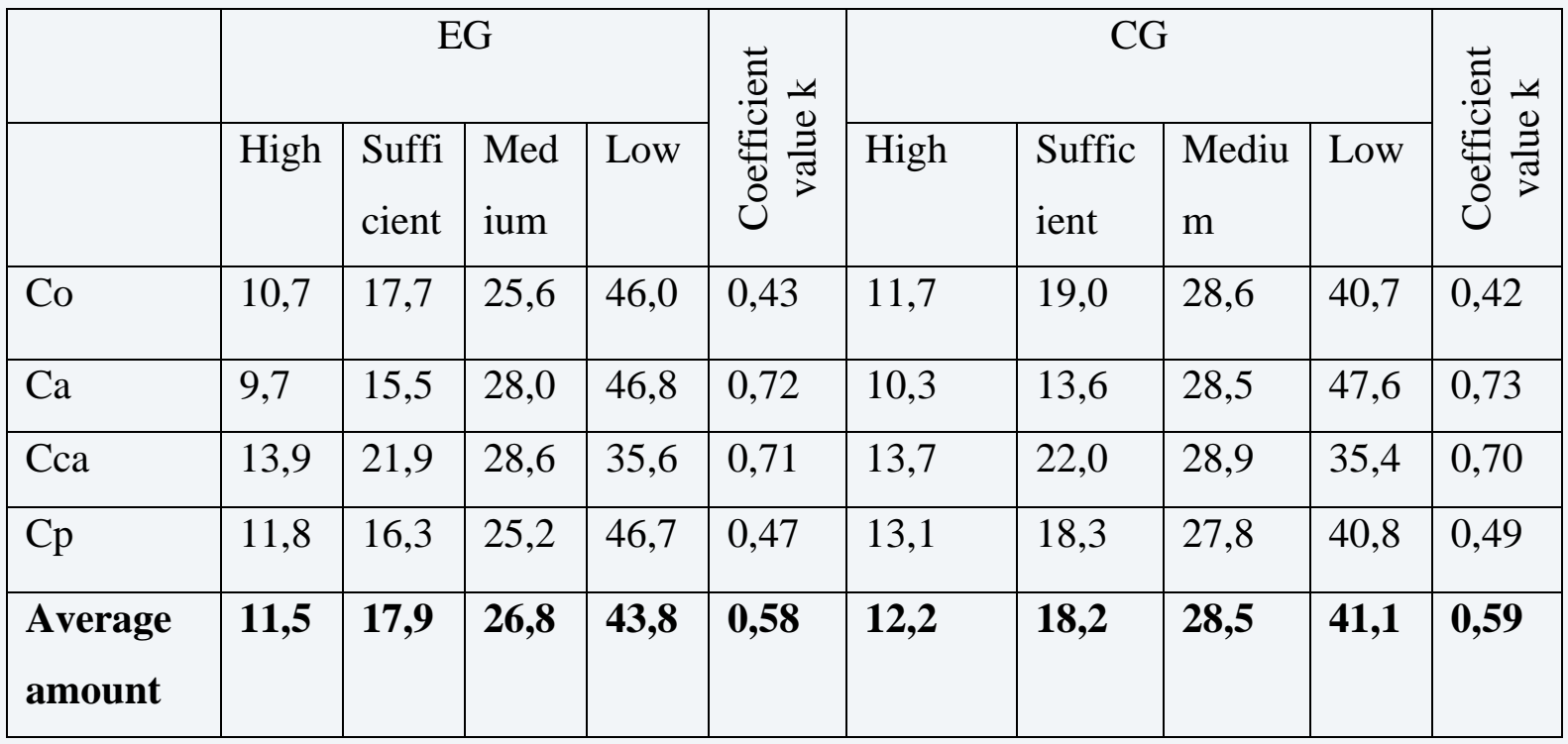

According to the table 2, the students' levels on the criteria of personification and cultural identity (coefficients are 0.47 for students of experimental and 0.59 for students of control groups) and value-patriotic outlook (0.43 and 0.42 respectively) are low.

Table 2. The results of the ascertaining study of the formation of the criteria of students' patriotic educatiedness

\begin{tabular}{|l|l|l|l|l|}
\hline \multirow{2}{*}{ Criterion } & \multicolumn{2}{|l|}{$\begin{array}{l}\text { Coefficient of } \\
\text { formation }\end{array}$} & \multicolumn{2}{l|}{ Level of formation } \\
\cline { 2 - 6 } & EG & CG & EG & CG \\
\hline Patriotic-directed activity & 0,72 & 0,73 & Medium & Medium \\
\hline Patriotic creative activity & 0,71 & 0,70 & Medium & Medium \\
\hline Value-patriotic outlook & 0,43 & 0,42 & Low & Low \\
\hline $\begin{array}{l}\text { Personification and cultural identity of the } \\
\text { individual }\end{array}$ & 0,47 & 0,49 & Low & Low \\
\hline \multicolumn{1}{|c|}{ Average amount } & $\mathbf{0 , 5 8}$ & $\mathbf{0 , 5 9}$ & Low & Low \\
\hline
\end{tabular}

Comparing the data with the characteristics of the levels of students' patriotic educatedness, we found out the initial level of formation of the studied quality (see Table 3 ).

Table 3. The initial level of students' patriotic educatedness, in \%

\begin{tabular}{|l|l|l|l|l|}
\hline Groups & High & Sufficient & Medium & Low \\
\hline
\end{tabular}




\begin{tabular}{|l|l|l|l|l|}
\hline Experimental groups & 11,5 & 17,9 & 26,8 & 43,8 \\
\hline Control groups & 12,2 & 18,2 & 28,5 & 41,1 \\
\hline
\end{tabular}

The results show that the majority of students in both control and experimental groups have low levels of patriotic educatedness (ranging from $40 \%$ to $50 \%$ ), only about $20 \%$ of the students show a high level.

\section{Conclusions}

In the course of the research we managed to achieve considerable and statistically significant changes in the levels of students' patriotic educatedness due to applying information and communication technologies. The quantitative, qualitative and statistical analyses were carried out after the experimental work had been completed, it revealed a tendency for positive changes. Statistical data analysis carried out by Student's t-test revealed significant changes for each criterion, balanced developing all the components of patriotic education within experimental groups, conditionality of changes by formative means. Changes are random for control groups. According to the results of experimental work in the control groups, no statistically significant changes in the levels of students' patriotic educatedness occurred. On the other hand, in the experimental groups there were $17.5 \%$ more students with high levels, $28.2 \%$ with sufficient ones due to a decrease of $45.6 \%$ of students with indicators of middle and low levels of patriotic educatedness. These findings are confirmed by qualitative and quantitative analysis, the results of Pearson's $\chi 2$ calculation. No coincidence of changes in the experimental groups was found on the highest level of statistical significance (0.01).

The results of the study can be used in the practice of teaching students of general secondary educational institutions, to serve as a basis for the development of mechanisms of students' patriotic education within educational process of general secondary educational institutions.

In our opinion, the areas of further research are: the search for mechanisms of preparing teachers of senior schools to work on patriotic education in general secondary educational institutions; identification of modern technologies, methods and techniques of students' patriotic education, and study of foreign experience on students' patriotic education with applying information and communication technologies. 


\section{REFERENCES}

1. Bodnar, S., Mirkovich, I., Koval, V. (2019). Human capital development in Ukrainian education system by means of language integrated teaching. Dilemas contemporaneoseducacion politica y valores, 7 (SI), 14.

2. Bukanov H., Kolesnyk A., Tashkinova O., Kotlubai V., Koval V. (2019). Social marketing in public administration of social service institutions. Revista Genero \& Direito, 8 (6), 457468.

3. Chace, J. (1997). An Extraordinary Partnership. Marshall and Acheson, 76, 191-194.

4. Chernega, P. (2012). Ukrainian ethnopedagogy - the science of the content, principles and methods of folk pedagogy of Ukrainians. The main directions of formation of professional qualities of specialists in educational work in the armed forces of Ukraine, 4, 65-67

5. Cichosz, W. (2013). Możliwości dialogu wychowania chrześcijańskiego ze współczesną edukacją polską. Wydawnictwo „Bernardinum”, Pelplin.

6. Demyanchuk, A. (2019). Psychological and pedagogical features of patriotism formation in senior preschoolers. Psychological and pedagogical bases of humanization of educational process in school and high school, 1, 13-20.

7. Dukhnovich, A. (2009). Folk pedagogy in favor of scientists and teachers. M.: Pedagogy.

8. Frączek, Z. (2006). Ojczyzna jako wartość edukacyjna w obliczu integracji europejskiej. in: Janiga W. (ed). Wychowanie do patriotyzmu. Przemyśl-Rzeszów, 3, 457-463.

9. George, F. (1946). "Long Telegram". The Makings of America: The United States and the World, 2, 299-303.

10. Goncharenko, C. (1997). Ukrainian Pedagogical Dictionary, 1, 34-36.

11. Janiga, W. (2004), Wychowanie patriotyczne dzieci i młodzieży w świetle dyrektorium katechetycznego i podstawy programowej katechezy kościoła katolickiego w Polsce. Resovia Sacra, 11, 213-225.

12. Kapska, A. (2001). Actual problems of social and pedagogical work (modular course of distance learning): Educ. Tool, 5, 119-129.

13. Koval, V., Polyezhayev, Y., \& Bezkhlibna, A. (2018). Communicative competences in enhancing of regional competitiveness in the labour market. Baltic Journal of Economic Studies, 4(5), 105-113. doi:10.30525/2256-0742/2018-4-5-105-113 
14. Kvitka, S., Starushenko, G., Koval, V., Deforzh, H., \& Prokopenko, O. (2019). Marketing of Ukrainian higher educational institutions representation based on modeling of Webometrics Ranking. Marketing and Management of Innovations, 3, 60-72. http://doi.org/10.21272/mmi.2019.3-05

15. Machuska, I. (2003). Pedagogical substantiation of the content of the program "Culture of interpersonal communication in the family", 6, 167-169.

16. Mishchenko, H (2004). What is the germ of patriotism? Native School, 2, 1-8.

17. Muszyński, H. (1996). Niektóre problemy kształtowania postaw patriotycznych dzieci i młodzieży. Kwartalnik Pedagogiczny, 3, 51-68.

18. Pustovit, G. (2015). Patriotic upbringing in the content of extracurricular education: present and prospects, 4 (20), 97-103.

19. Shinkaruk, B (1986). Patriotism: A Philosophical Dictionary, 2, 46-48.

20. Shynkarenko, B (2017). Information technologies as a means of patriotic upbringing of pupils in the educational process of secondary schools, 2 (12), 174-178.

21. Shynkarenko, In (2018). Criteria and indicators of patriotic upbringing of high school students in the educational process of institutions of general secondary education, 2 (94), 156-170.

22. Vygotsky, L. (1991). Pedagogical Psychology, M.: Pedagogy.

23. Zyazyun, I (2000). Pedagogy of the good: ideals and realities: Scientific method. K .: MAUP.

\section{SOBRE OS AUTORES:}

\section{Vyacheslav Shynkarenko}

$\mathrm{PhD}$ in Pedagogical Sciences, Head of the Department of Preschool and Primary Education of Communal Institution of Higher Education «Dnipro Academy of Continuing Education» of Dnipropetrovsk Regional Council, Dnipro, Ukraine.E-mail: kafec@ukr.net

(iD http://orcid.org/0000-0003-0929-9160

\section{Olha Perederii}

$\mathrm{PhD}$ in Pedagogical Sciences, Associate Professor of the Department of Preschool and Primary Education of Communal Institution of Higher Education «Dnipro Academy of Continuing Education» of Dnipropetrovsk Regional Council, Dnipro, Ukraine. E-mail: kafec@ukr.net 
D http://orcid.org/0000-0002-1923-6780

\section{Bezena Ivan}

$\mathrm{PhD}$ in Philosophy, Head of the Department of Social and Humanitarian Education of Communal Institution of Higher Education «Dnipro Academy of Continuing Education» of Dnipropetrovsk Regional Council, Dnipro, Ukraine. -mail: kafec@ukr.net

(iD http://orcid.org/0000-0002-7169-2038

\section{Yevheniia Velykodna}

$\mathrm{PhD}$ in Philosophy, Associate Professor of the Department of Management of Information and Educational Projects of Communal Institution of Higher Education «Dnipro Academy of Continuing Education» of Dnipropetrovsk Regional Council, Dnipro, Ukraine. -mail: kafec@ukr.net

\section{(iD http://orcid.org/0000-0002-6350-5415}

\section{Andrii Miroshnychenko}

$\mathrm{PhD}$ in Philosophy, Associate Professor,

Department of Information and Educational Projects Management,

Communal Institution of Higher Education «Dnipro Academy of Continuing Education» of Dnipropetrovsk Regional Council, Dnipro, Ukraine. E-mail: kafec@ukr.net

(iD http://orcid.org/0000-0002-9973-018X

Recebido em: 18 de novembro de 2019

Aprovado em: 21 de dezembro de 2019

Publicado em: 27 de março de 2020 